\title{
Mesothelioma mortality surveillance and asbestos exposure tracking in Italy
}

\author{
Lucia Fazzo $^{(\text {a) }}$, Giada Minelli ${ }^{(b)}$, Marco De Santis ${ }^{(a)}$, Caterina Bruno ${ }^{(a)}$, Amerigo Zona ${ }^{(a)}$, \\ Alessandro Marinaccio ${ }^{(\mathrm{c})}$, Susanna Conti ${ }^{(\mathrm{b})}$, Roberta Pirastu ${ }^{(\mathrm{d})}$ and Pietro Comba ${ }^{(\mathrm{a})}$ \\ ${ }^{(a)}$ Dipartimento di Ambiente e Connessa Prevenzione Primaria; \\ (b) Ufficio di Statistica, Istituto Superiore di Sanità, Rome, Italy \\ (c) Dipartimento Medicina del Lavoro, Registro Nazionale dei Mesoteliomi, \\ Istituto Nazionale per l'Assicurazione contro gli Infortuni sul Lavoro, Rome, Italy \\ (d) Dipartimento di Biologia e Biotecnologie “Charles Darwin”, Sapienza Università di Roma, Rome, Italy
}

\begin{abstract}
Introduction. Spatial distribution of mortality from pleural mesothelioma (which in the ICD-10 Revision has a specific code: C45.0) in Italy for the period 2003-2009 is described. Previous mortality studies at national level employed the topographic code "Malignant neoplasms of pleura", because of unavailability of a specific code in ICD-9 Revision for pleural mesothelioma. Methods. Standardized mortality ratios were computed for all municipalities, using each regional population as reference; for municipalities in Regions with rate higher than the national rate, the latter has been used as reference. SMRs were computed specifically also for each Italian Polluted Sites "of national concern for environmental remediation" (IPS) with asbestos exposure sources, composed by one or more municipalities, using regional rate as reference. Spatial Scan Statistics procedure, using SatScan software, was applied in cluster analysis: the country was divided into geographic macro-areas and the relative risks (RR) express the ratio of risk within the cluster to the risk of the macro-area outside the cluster. Clusters with p-value $<0.10$ were selected. Results. The national standardized annual mortality rate was 1.7 cases per 100000 . Several areas with evident burden of asbestos-related disease were detected. Significant clusters were found in correspondence to asbestos-cement industries (e.g. Casale Monferrato, women: RR = 28.7), shipyards (e.g. Trieste, men: $\mathrm{RR}=4.8$ ), petrochemical industries (e.g. Priolo, men: $\mathrm{RR}=6.9)$ and a stone quarry contaminated by fluoro-edenite fibres (Biancavilla, women: $R R=25.9$ ). Some of the increased clusters correspond to IPS. Conclusions. The results may contribute to detect asbestos exposure and to set priorites for environmental remediation.
\end{abstract}

Key words: mesothelioma, geographic mortality, asbestos, polluted sites.

Riassunto (Analisi della mortalità per mesotelioma ed esposizione ad amianto in Italia). Introduzione. Viene illustrata la distribuzione spaziale in Italia della mortalità per mesotelioma pleurico (che nella decima revisione ICD ha un codice specifico: C45.0) per gli anni 2003-2009. Studi precedenti a livello nazionale avevano invece utilizzato il codice topografico "Tumori maligni della pleura", in assenza di un codice specifico in Nona Revisione ICD per il mesotelioma pleurico. Metodi. I rapporti standardizzati di mortalità (SMR) sono stati calcolati per tutti i comuni, utilizzando la popolazione regionale come riferimento; per i comuni in Regioni con un tasso maggiore di quello nazionale, è stato utilizzato quest'ultimo come riferimento. SMR sono stati calcolati anche specificatamente per i siti di interesse nazionale per le bonifiche (SIN) con sorgenti di esposizione ad amianto, composti da uno o più comuni, rispetto al tasso regionale. Il software Spatial Scan Statistic SatScan è stato utilizzato per l'analisi dei cluster: il territorio nazionale è stato suddiviso in macro-aree regionali e i rischi relativi (RR) esprimono il rapporto del rischio all'interno del cluster rispetto al rischio del resto della macro-area. Cluster con un valore di $\mathrm{p}<0,10$ sono stati selezionati. Risultati. Il tasso standardizzato nazionale annuo è di 1,7 casi per 100000 . Cluster significativi sono stati trovati in corrispondenza di industrie del cemento-amianto (ad es. Casale Monferrato, donne: $\mathrm{RR}=28,7$ ), aree portuali (ad es. Trieste, uomini: $\mathrm{RR}=4,8)$ e poli petrolchimici (ad es. Priolo, uomini: $\mathrm{RR}=6,9$ ); un cluster è stato identificato a Biancavilla (donne: $\mathrm{RR}=$ $25,9)$, dove è presente una cava di materiale contaminato da fluoro-edenite. Alcuni cluster significativi corrispondono a SIN. Conclusioni. I risultati contribuiscono a identificare esposizioni ad amianto prioritarie per la bonifica ambientale.

Parole chiave: mesotelioma, mortalità, amianto, siti inquinati. 


\section{INTRODUCTION}

The objective of the present study was to evaluate the geographic distribution in Italy of areas characterized by high mortality due to asbestos-related diseases. The importance of evaluating the distribution lies in the fact that it could contribute to detecting asbestos exposure and establishing priorities for environmental remediation, in the perspective of environmental public health tracking.

In this context, pleural mesothelioma is the main disease of interest, since it is induced almost exclusively by exposure to asbestos both occupational and environmental [1], and the only other known risk factors are exposure to erionite [2] and fluoro-edenite [3]. In Italy, pleural mesothelioma mortality has been extensively investigated at the municipality level [4-8] and the studies that have been conducted have ensured full coverage of the period 1980-2002. In 1980-2002 the $9^{\text {th }}$ Revision of the International Classification of Disease (ICD) was used in Italy, and the topographic code for "Malignant neoplasms of pleura" (ICD 163.0163.9) was employed as an indirect indicator for estimating occurrence of pleural mesothelioma. However, the use of this code resulted in a certain degree of misclassification at the individual level, though it was shown to be appropriate at the population level because of a sort of a kind of compensation between false-positives and false-negatives [9, 10]. Since 2003 Italy has adopted the $10^{\text {th }}$ Revision of the ICD, which has an ad hoc morphologic code for pleural mesothelioma (C45.0). Subsequent to this change there were $20 \%$ fewer cases [8] and accuracy improved. The present study refers to the years 2003-2009, which is the most recent period for which mortality data are available (excluding the years 2004 and 2005, for which coded data are not yet available).

The National Mesothelioma Register (ReNaM), located at the former National Institute for Occupational Safety and Health (ISPESL) (currently known as the "Italian National Workers Compensation Authority", INAIL), has existed since 1993, with the remit of estimating the incidence of malignant mesothelioma in Italy, investigating the occurrences of asbestos exposure, identifying any possible underrated or unknown source of asbestos contamination and promoting research. ReNaM has published data on incidence and on jobs associated with asbestos exposure [11], survival [12, 13], latency [14] and the predictions for mesothelioma deaths in the next years [15]. Currently, data on incident cases of mesothelioma (based on histologically confirmed diagnoses) are available for the period 2003-2008 for a large part of the country (more than $15000 \mathrm{ma}-$ lignant mesothelioma cases at the whole). For more than 12000 cases $(76 \%$ of the incident cases recorded) data on occupational and residential history and lifestyle habits, have been collected.

Major developments in asbestos exposure mapping have also taken place in recent years because of the commitment of the Ministry of the Environment which identified a great number of sites (about 34000 ) characterized by different amounts and modes of asbestos presence; these sites are currently candidates for remediation activities [16]. A limited number of sites (no. $=12$ ) were recognized as being of national concern for environmental remediation because of a greater presence of asbestos and an ongoing health risk. The boundaries of Italian polluted sites (IPS) are defined on the basis of health, environmental and social criteria (Decree 152/06). In 2011, there were 57 IPSs, of which 44 were included in the SENTIERI Project which analyzed mortality among residents for the years 1995-2002. The results of the mortality analysis, including those for "Malignant neoplasms of pleura" (ICD 163.0-163.9) in each site and in all sites combined were published in 2011 [17].

In the present study, mortality for pleural mesothelioma (ICD-10 Rev: C45.0) was analysed for the period 2003-2009 (excluding the years 2004 and 2005) in the IPSs of the SENTIERI Project characterized by the presence of sources of asbestos exposure. As anticipated in the previous paragraph, asbestos was listed in the Decree for 12 out of 44 sites; in 6 sites only sources of asbestos/mineral fibers were listed: Emarese and Balangero (asbestos, quarry and dumping sites), Broni, Casale Monferrato and Bari-Fibronit (asbestos-cement factory), Biancavilla (fluoro-edenite quarry). In the remaining 6 sites, asbestos was recorded together with one or more other sources of environmental exposures (Area Litorale vesuviano, Aree industriali Val Basento, Massa Carrara, Pitelli, Priolo and Tito).

\section{MATERIALS AND METHODS}

The source of data was the National Mortality Database (NMD), which is managed by the Statistics Unit of the Istituto Superiore di Sanità (Italy's National Health Institute) and based on data provided by ISTAT (Italy's National Statistics Institute). This database contains the underlying cause of death, which until 2003 was coded using the Ninth Revision of ICD (ICD-9); since then, the $10^{\text {th }}$ Revision (ICD-10) has been used (www.who/int/ classifications/icd/en/). In the NMD, data are available from 1980 to 2009, except for the years 2004 and 2005, for which coded data are not yet available. Mortality from pleural mesothelioma was defined using the specific ICD-10 Code: C45.0.

The denominators used for the mortality rates are the sum of the annual residential populations for the considered study period (2003-2009, excluding 2004 and 2005).

The analysis was conducted for all 8094 municipalities in Italy. The number of observed deaths for pleural mesothelioma among residents in each municipality was compared to the expected number of deaths based on national and regional rates.

We calculated the national rates specific for age-class and gender and their corresponding 95\% confidence 


\begin{tabular}{|c|c|c|c|c|c|c|c|c|c|c|c|c|}
\hline \multirow[b]{2}{*}{ Gender } & \multicolumn{4}{|c|}{$0-39$} & \multicolumn{4}{|c|}{$40-75$} & \multicolumn{4}{|c|}{ 76-99 } \\
\hline & $\begin{array}{l}\text { Observed } \\
\text { cases }\end{array}$ & $\begin{array}{l}\text { Standardized } \\
\text { rates }\end{array}$ & $\begin{array}{l}\text { Lower } \\
95 \% \mathrm{CI}\end{array}$ & $\begin{array}{l}\text { Upper } \\
\mathbf{9 5 \%} \mathrm{CI}\end{array}$ & $\begin{array}{l}\text { Observed } \\
\text { cases }\end{array}$ & $\begin{array}{l}\text { Standardized } \\
\text { rates }\end{array}$ & $\begin{array}{l}\text { Lower } \\
95 \% \mathrm{CI}\end{array}$ & $\begin{array}{l}\text { Upper } \\
95 \% \text { Cl }\end{array}$ & $\begin{array}{l}\text { Observed } \\
\text { cases }\end{array}$ & $\begin{array}{l}\text { Standardized } \\
\text { rates }\end{array}$ & $\begin{array}{l}\text { Lower } \\
\mathbf{9 5 \%} \mathrm{CI}\end{array}$ & $\begin{array}{l}\text { Upper } \\
95 \% \text { I }\end{array}$ \\
\hline Men & 8 & 0.01 & 0.005 & 0.02 & 2427 & 4.60 & 4.37 & 4.84 & 1270 & 13.78 & 13.02 & 14.58 \\
\hline Women & 7 & 0.01 & 0.004 & 0.02 & 800 & 1.34 & 1.23 & 1.46 & 672 & 4.17 & 3.83 & 4.51 \\
\hline Total & 15 & 0.01 & 0.01 & 0.02 & 3227 & 2.84 & 2.72 & 2.97 & 1942 & 7.70 & 7.35 & 8.06 \\
\hline
\end{tabular}

intervals $(\mathrm{CI})$, and the standardized mortality rates for each of the 21 Regions/Autonomous Provinces, using as standard population the national population according to the 2001 census.

Standardized mortality ratios (SMRs) were calculated for each municipality. The age-specific and gender-specific expected mortality rates based on national or regional mortality rates with $90 \% \mathrm{CI}$ were estimated based either on a Poisson distribution, if there were fewer than 100 observed cases, or using the Byar method, if there were more than 100 observed cases. The age-specific and gender-specific rates of each regional population were used as reference in calculating the expected mortality rates; for municipalities in Regions in which the standardized or crude rate was higher than the national rate, we used the national rate as reference, so as not to underestimate the SMRs.

Given the rarity of mesothelioma, which results in a very low expected mortality in many municipalities, an SMR-based surveillance system may be affected by random variation and generate a number of positive results by chance. For this reason, and given the fact that asbestos facilities tend to be concentrated in specific geographic areas, we performed a municipal clustering analysis to identify the areas with major departures from expected mortality. For this analysis, the country was divided into geographic macro-areas, each consisting of several Regions: North-West (Piemonte, Lombardia, Liguria, Val d'Aosta); North-East (Veneto, Friuli-Venezia Giulia, Trentino), Central (Emilia-Romagna, Toscana, Umbria, Marche, Lazio, Abruzzo); South (Molise, Campania, Puglia, Basilicata, Calabria); and the main islands, considered separately (Sicilia and Sardegna).

The analysis was performed according to the procedure Spatial Scan Statistics [18], using SatScan software (version 6). The procedure employs a circular window of varying radius from zero to some upper limit, which moves on the entire study area, centred at each step on one of the municipalities, identified by the $\mathrm{x}$, $\mathrm{y}$ coordinates of the municipality's town hall. The method creates an infinite number of distinct geographical circles with different sets of neighbouring data locations within them: each circle is a possible candidate for a cluster. Under the null hypothesis, the observed number of cases follows a uniform distribution, so that the expected number of cases in an area is proportional to its population size. Clusters of interest are selected on the basis of the p-value associated to their likelyhood under the null hypothesis $(\mathrm{p}<0.10)$. The relative risk is the estimated risk within the cluster divided by the estimated risk outside of the cluster.

On the basis of the studies of environmental risk for residents near an asbestos-cement facility in the town of Casale Monferrato [19], a maximum radius of $11 \mathrm{~km}$ was fixed.

In the analysis for IPSs the method used in the SENTIERI Project was applied. The SMRs for each IPS, which consist of one or more municipalities, were computed using regional rates.

\section{RESULTS \\ Standardized rates}

The standardized annual mortality rates from pleural mesothelioma in Italy in the study period was 1.7 per 100000 inhabitants; the rate was 4.60 among men and 1.34 among women in the 40-75 year age class (Table 1). The present results confirm the highest rates in some Northern Regions: Friuli-Venezia Giulia (3.0); Liguria (5.4), Lombardia (2.4) and Piemonte (3.0). Table 2 shows the annual regional rates by genders.

\section{Standardized mortality ratios}

Significantly increased SMRs were found in 263 municipalities, with a geographical distribution that confirms the well known north-southern gradient in pleural mesothelioma mortality in Italy (Figure 1).

\section{Cluster analysis}

The significant clusters by macro-area and gender are shown in Figures 2 and 3.

In all macro-areas, there were fewer municipalities that constituted significant clusters when the analysis was conducted among women, compared to men.

In the North-East, women did not show significant clusters; both significant clusters detected among men (Trieste and Monfalcone areas) corresponded to areas with harbour, shipbuilding and repair industries. 


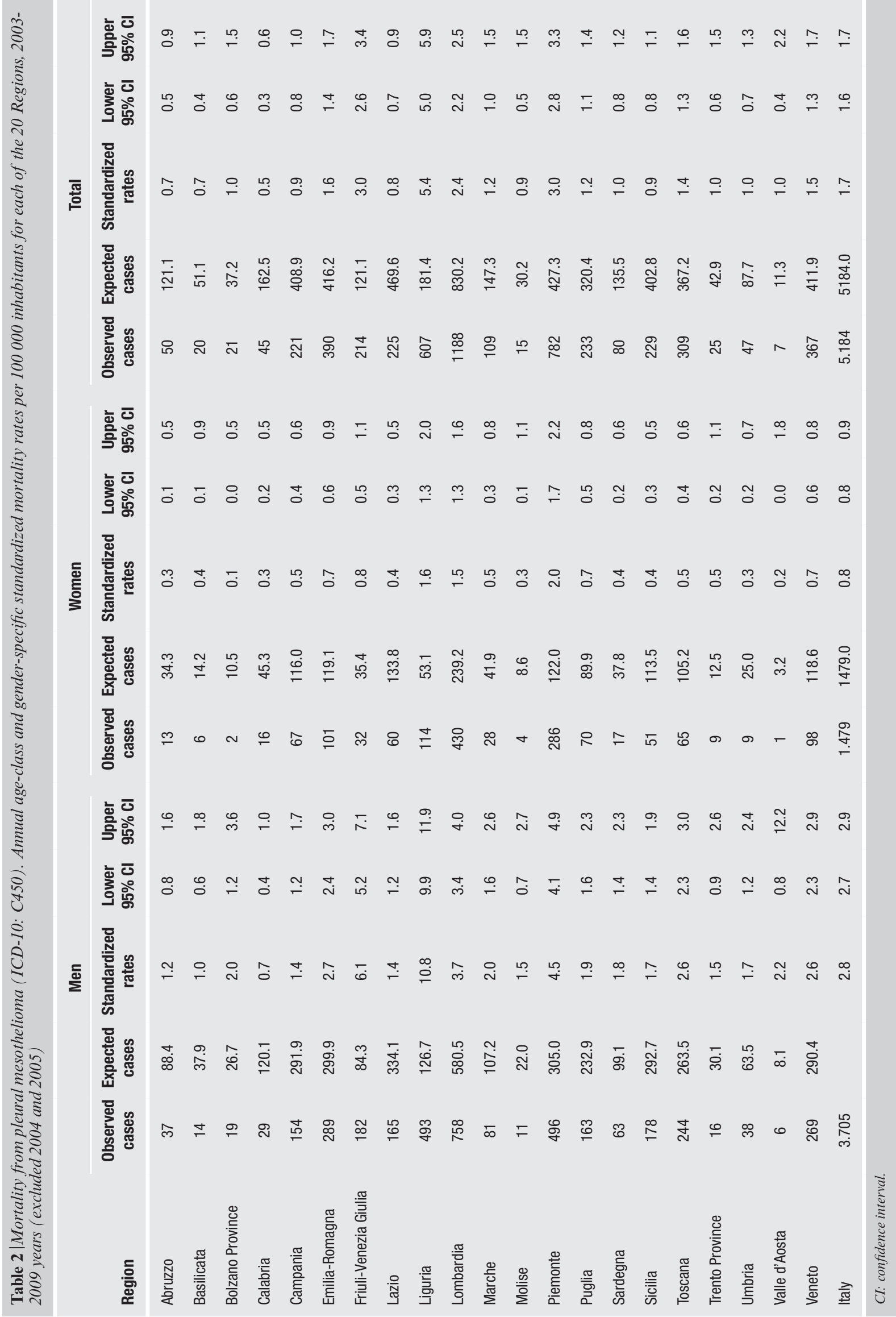



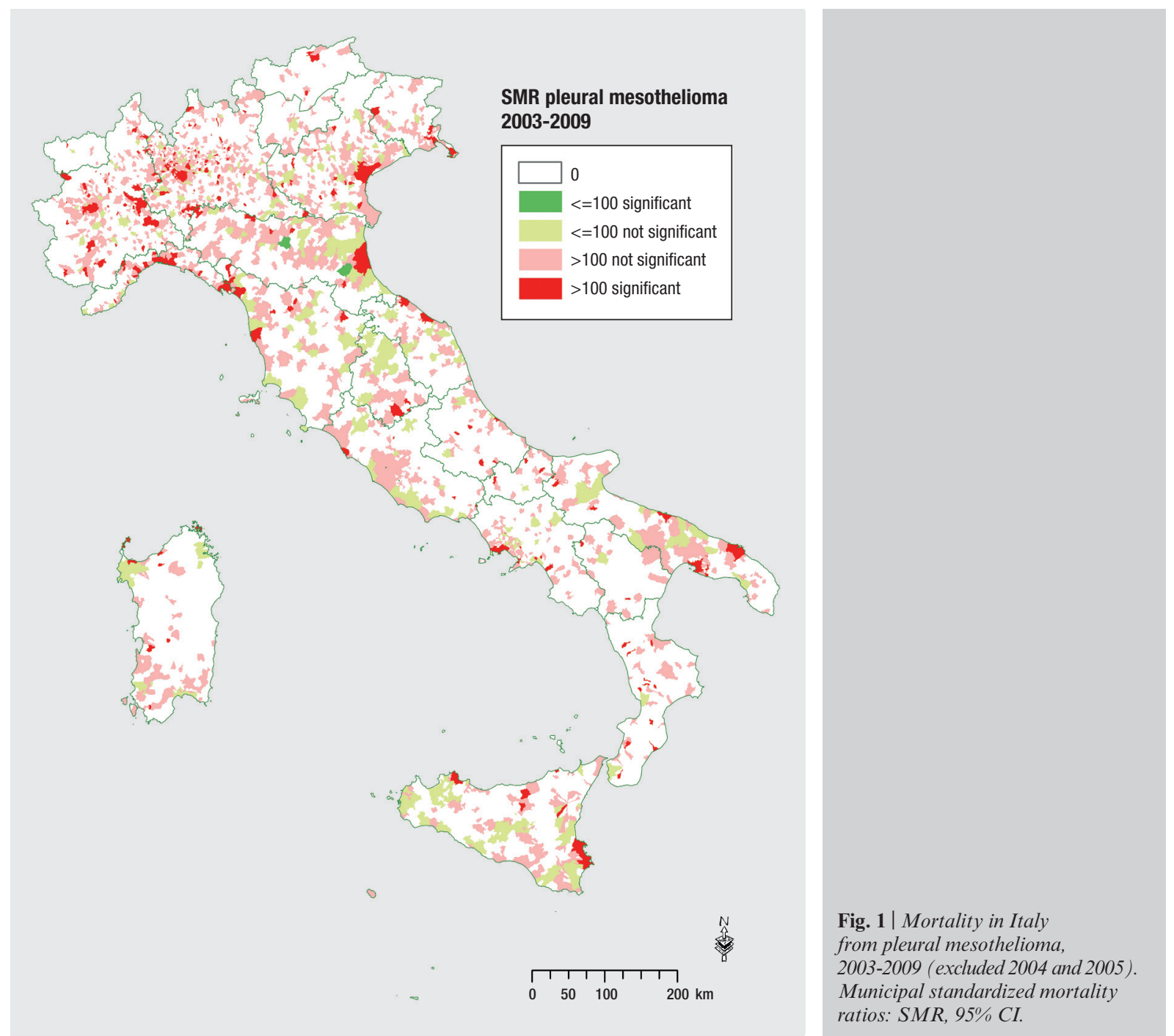

In the North-West, three significant clusters were found for women and four for men. Two clusters found in both genders corresponded to the areas with major asbestos-cement industries (Casale Monferrato and Broni); two male clusters are located in Liguria, where harbour, shipbuilding and repair industries are present; oil refineries plants are also operating in these areas. In the Central Italy macro-area two significant clusters were detected in the analysis among women and five among men. Three of the latter are constituted by one municipality: Livorno $(\mathrm{RR}=5.1)$, where a major harbour is located, Ravenna ( $\mathrm{RR}=3.3)$, with harbour and chemical industry site, and Collesalvetti $(\mathrm{RR}=8.4)$; the latter is located close to Livorno, so that a common source of asbestos exposure may be hypothesized.

In the South, clusters in the same areas are present for both genders: Bari, with an asbestos-cement industry and Taranto, where a harbour, a large steel foundry and oil refinery are located.

In Sicily a significant cluster was found among women, corresponding to the Biancavilla municipality $(R R=25.9)$, characterized by the presence of a quarry contaminated by fluoro-edenite not detected as a cluster in previous national studies, but always expressing elevated SMRs. In men, one of the significant clusters includes the Priolo area, where an oil refinery and a petrochemical industry are operating; the other one is the Siracusa municipality $(\mathrm{RR}=3.8)$, where an asbestos-cement industry was present. The latter one was not detected in the previous analysis.

No significant clusters were detected in Sardegna.

Table 3 shows mortality results in IPS with asbestos contamination for males and females in the period 1995-2002 [17] and the following period 2003-2009. A formal comparison is precluded by the change in the ICD Revision, but some comments are warranted.

Among males, in nine sites the increased risk is present in both periods; in one site (Area Val Basento) no cases were recorded in 1995-2002 and an increase is present in the most recent period (3 Obs; SMR 430; 90\% CI 117-111).

For females in five sites the observed mortality is above expected in both periods; in one site (Area Litorale Vesuviano) an increase is present only in 


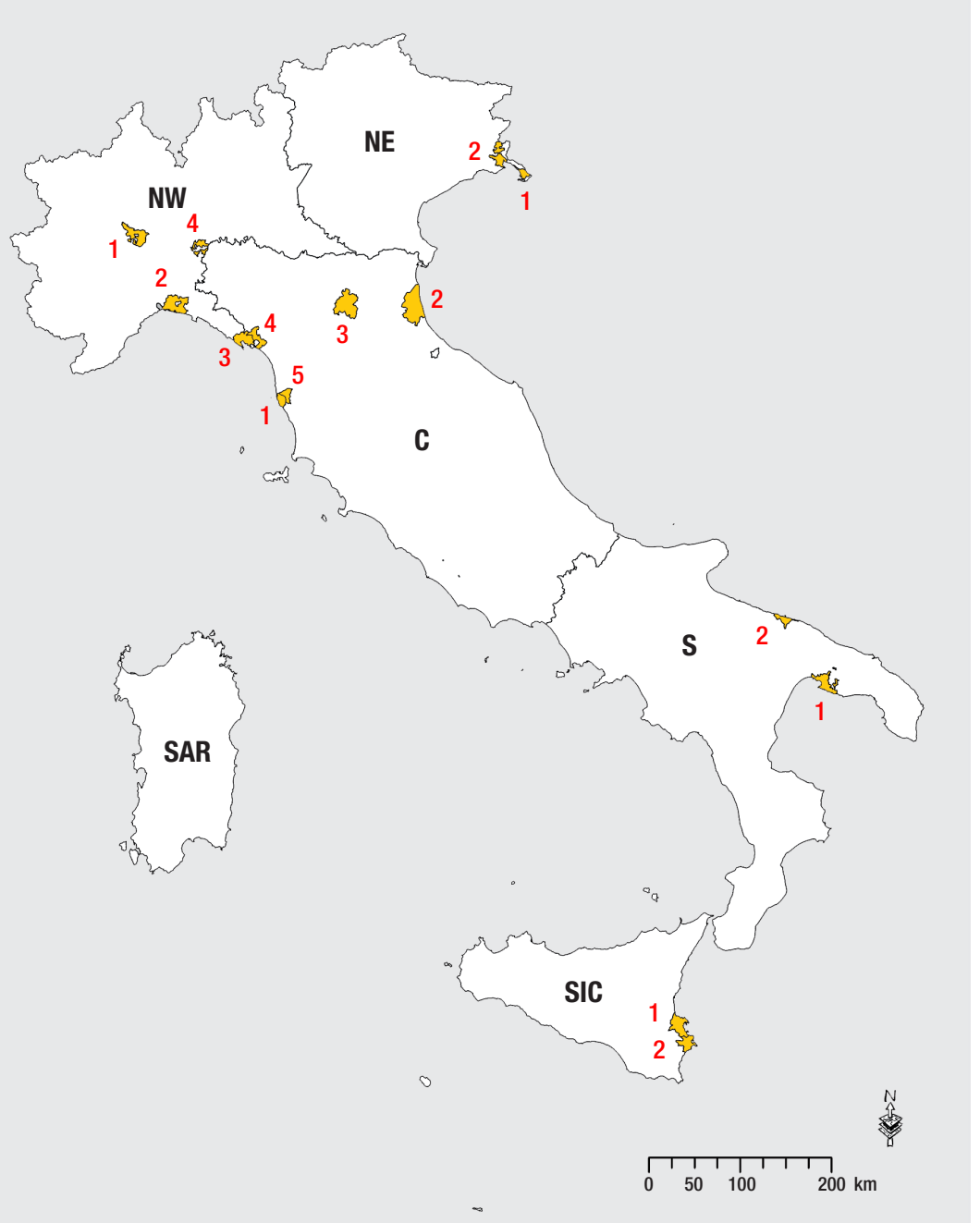

Fig. $2 \mid$ Mortality from

pleural mesothelioma among men in Italy, 2003-2009 (excluded 2004 and 2005).

Significant clusters ( $p$-value $<0.10)$

in each macro-area.

Municipalities indicated in the table below are:

a: Muggia, Trieste

b: Gradisca d'Isonzo, Fogliano Redipuglia, Farra d'Isonzo, Mariano del Friuli, Romans d'Isonzo, San Pier d'Isonzo, Capriva del Friuli, Ronchi dei Legionari, Cormons, Campolongo Tapogliano, Turriaco, Ruda, San Canzian d'Isonzo, Monfalcone, Staranzano

c: Morano sul Po, Pontestura, Balzola, San Giorgio Monferrato, Treville, Camino, Casale Monferrato, Trino, Rosignano Monferrato, Sala Monferrato, Cella Monte, Serralunga di Crea, Terruggia, Villanova Monferrato

d: Sant'Olcese, Serra Riccò, Mignanego, Ceranesi, Casella, Campomorone, Montoggio, Genova

e: La Spezia, Vezzano Ligure, Arcola, Portovenere, Follo, Lerici, Santo Stefano di Magra, Riccò del Golfo di Spezia, Riomaggiore, Sarzana, Bolano f: Canneto Pavese, Broni, Santa Maria della Versa, Zenevredo, Stradella, Rovescala, Santa Giulietta, Montalto Pavese, Barbianello, Campospinoso, Bosnasco, Portalbera, Corvino San Quirico g: Livorno

h: Ravenna

i: Casalecchio di Reno, Zola Predosa, Monte San Pietro, Bologna, Sasso Marconi, Calderara di Reno, Pianoro

: Fosdinovo, Carrara, Aulla

k: Collesalvetti

Taranto, Leporano, Pulsano

m: Bari

: Augusta, Priolo Gargallo, Melilli

o: Siracusa

\begin{tabular}{|c|c|c|c|c|c|c|}
\hline Area & Cluster number & Ray (meters) & $\begin{array}{c}\text { Number of } \\
\text { municipalities }\end{array}$ & Observed & Expected & RR \\
\hline NE & 1 & 4796 & $2^{\mathbf{a}}$ & 81 & 19.47 & 4.799 \\
\hline NE & 2 & 9997 & $15^{\mathbf{b}}$ & 51 & 8.04 & 6.976 \\
\hline NW & 1 & 9343 & $1^{\mathbf{c}}$ & 98 & 7.73 & 13.381 \\
\hline NW & 2 & 8366 & $8^{\mathbf{d}}$ & 259 & 86.77 & 3.331 \\
\hline NW & 3 & 9639 & $1^{\mathbf{e}}$ & 107 & 23.33 & 4.82 \\
\hline NW & 4 & 8845 & $1^{\mathbf{f}}$ & 29 & 6.05 & 4.685 \\
\hline C & 1 & - & $1^{\mathbf{g}}$ & 42 & 8.51 & 5.141 \\
\hline C & 2 & - & $1^{\mathbf{h}}$ & 26 & 8 & 3.322 \\
\hline C & 3 & 10593 & $7^{\mathbf{i}}$ & 55 & 27.24 & 2.089 \\
\hline C & 4 & 9916 & $3^{\mathbf{j}}$ & 16 & 4.12 & 3.943 \\
\hline C & 5 & - & $1^{\mathbf{k}}$ & 7 & 0.84 & 8.38 \\
\hline S & 1 & 10667 & $3^{\mathbf{1}}$ & 47 & 6.44 & 8.222 \\
\hline S & 2 & - & $1^{\mathbf{m}}$ & 26 & 10.19 & 2.67 \\
\hline SIC & 1 & $3^{\mathbf{n}}$ & 13 & 2.01 & 6.909 \\
\hline SIC & 2 & - & $1^{\mathbf{0}}$ & 15 & 4.23 & 3.784 \\
\hline
\end{tabular}

1995-2002; in two sites (Massa Carrara and Pitelli) an increased risk is registered only in 2003-2009, with the SMRs equal to, respectively, 127 (3 Obs; 90\% CI 35-327) and 147 (4 Obs; 90\% CI 77-518).
In 5 of the 6 IPSs where asbestos was recorded together with one or more other environmental exposures mortality in 2003-2009 is lower than in 19952002 in both genders. Considering all IPSs combined, 


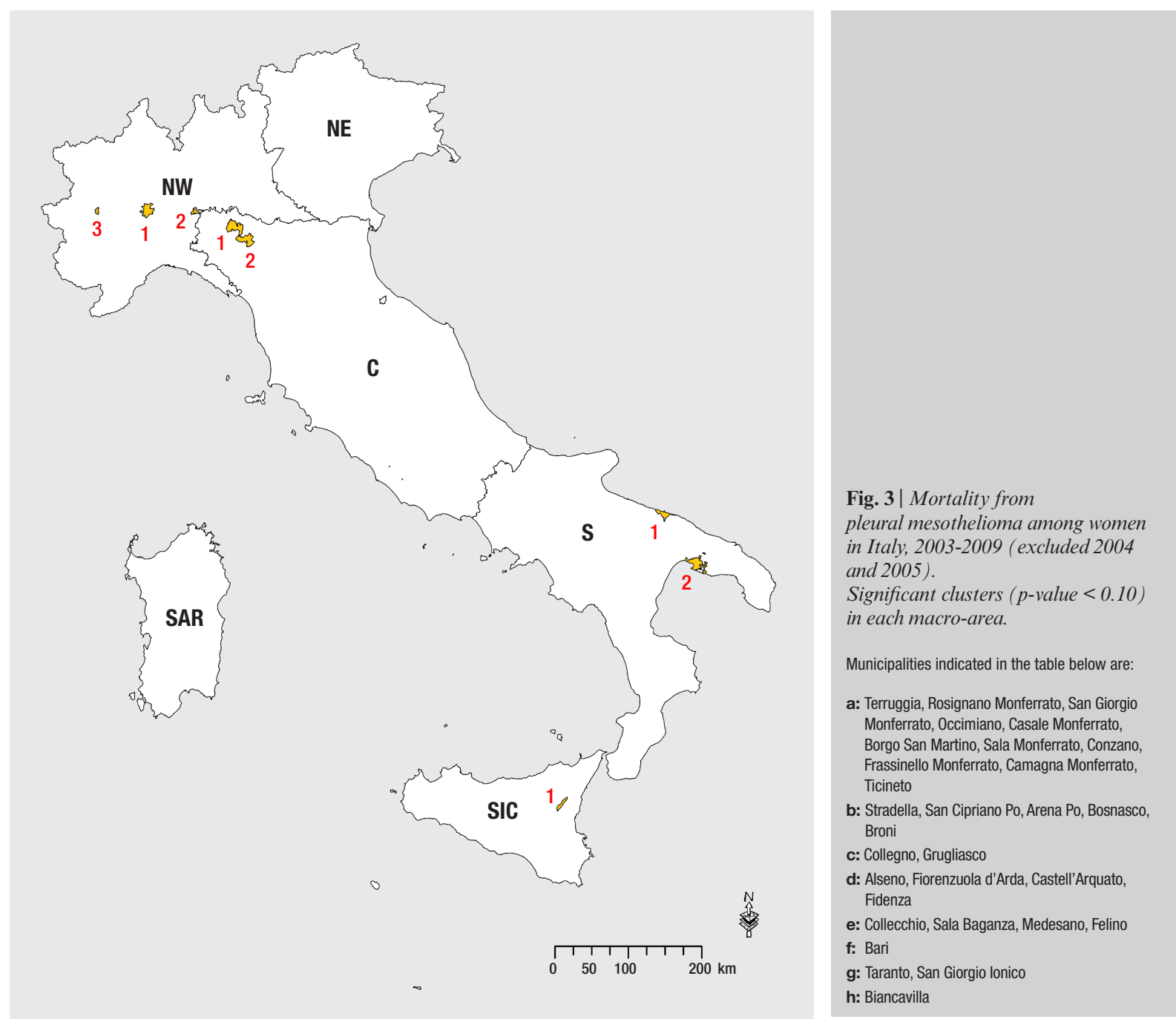

\begin{tabular}{|c|c|c|c|c|c|c|}
\hline Area & Cluster Number & Ray (meters) & $\begin{array}{c}\text { Number of } \\
\text { municipalities }\end{array}$ & Observed & Expected & RR \\
\hline NW & 1 & 8677 & $11^{\mathbf{a}}$ & 82 & 3.16 & 28.743 \\
\hline NW & 2 & 5706 & $5^{\mathbf{b}}$ & 28 & 1.69 & 17.115 \\
\hline NW & 3 & 1132 & $2^{\mathbf{c}}$ & 18 & 4.17 & 4.389 \\
\hline C & 1 & 9153 & $4^{\mathbf{d}}$ & 8 & 0.86 & 9.573 \\
\hline C & 2 & 6711 & $4^{\mathbf{e}}$ & 6 & 0.54 & 11.3 \\
\hline S & 1 & - & $1^{\mathbf{f}}$ & 17 & 4.59 & 4.023 \\
\hline S & 2 & 8939 & $2^{\mathbf{g}}$ & 13 & 3.19 & 4.342 \\
\hline SIC & 1 & - & $1^{\mathbf{h}}$ & 5 & 0.21 & 25.894 \\
\hline
\end{tabular}

the overall cases where 641 in the 1995-2002 and 447 in 2003-2009 (excluding the years 2004 and 2005).

\section{DISCUSSION}

This is the first national level study of asbestosrelated disease mortality, using the specific code of pleural mesothelioma, available in ICD-10, adopted in Italy since 2003. As described in the introduction, the code used until 2002 "pleural malignant neoplasms" implied an overestimation of pleural mesothelioma of about $20 \%$. Thus, the present estimates are lower in absolute terms, yet the SMRs and RRs should be more accurate. The annual rate based on ICD-10 is 1.7 cases per 100000 , compared to the previous estimate of 1.9 cases per 100000 . Notwithstanding the possible underestimation, in the investigated IPSs the annual number of cases of pleural mesothelioma in the period 2003-2009 years (excluding 2004 and 2005) was 89, compared to the 80 cases per year of malignant neoplasms of pleura in the period in which ICD-9 was used. In a recent 
paper on pleural mesothelioma mortality in Spain, both ICD revisions were used to estimate the impact of asbestos on health, and this is said to be the accepted way to complete the mortality series [20].

Several identified clusters are in areas already studied and the risk of mesothelioma was attributed to occupational or environmental asbestos exposure.

Increased risk for mesothelioma in the Northeastern clusters (Trieste and Monfalcone) has been attributed to the presence of a large shipbuilding industry [21-25].

In the North-western macro area, significant clusters have been identified that include one or more municipalities previously investigated: Casale Monferrato (asbestos-cement industry), [26-28], and Broni (asbestos-cement industry) [29, 30]. Shipbuilding and repair industries are known sources of asbestos exposure in Genoa and La Spezia (Genoa by Puntoni et al., 2001 [31]; La Spezia by Dodoli et al., 1992 [32] and Gennaro et al., 2000 [33]). In the Grugliasco area, mesothelioma in textile workers has been investigated $[34,35]$.

Some of the cluster areas in the Central macro area have already been investigated: Ravenna, where an harbour and a chemical industry are located [36], Carrara (asbestos-cement industry) [37], Livorno (shipbuilding and repair, harbour, oil refinery) [32, $10,38]$. On the other hand, no information is currently available to allow us to comment on the cluster of Collesalvetti (municipality close to Livorno). Pleural mesothelioma cases among workers in railway carriages construction and repair of Bologna were studied [39]. An old oil refinery is located in Fiorenzuola d'Arda.
In the South area a cluster is represented by a municipality (Bari), where a major asbestos-cement industry operated; this source of exposure was considered in studies conducted by different authors, with respect to both occupational and environmental exposures [40-42, 28]. Graziano et al., 2009 [43], studied the area of Taranto, included in a cluster, where shipbuilding and repair facility, a foundry and a refinery are located.

In Sicily three mesothelioma clusters were identified.

The Biancavilla case, where no industrial activities related to asbestos had occurred, is well known because of an outbreak of mesothelioma. Previous studies suggested an etiological role of the asbestiform fiber found in a stone quarry whose products were used in the local building industry and in road paving. The fiber, a new mineral species named fluoro-edenite, was demonstrated to induce mesotheliomas in animals. The town of Biancavilla is still facing an epidemic of pleural mesothelioma as a consequence of the environmental exposure to fluoro-edenite [44]. The cluster identified among women corroborates the role of the environmental exposure to the fibre.

Clusters of Siracusa and Augusta, Priolo, Gargallo are located in a polluted site of national interest for remediation. Large refinery and petrochemical industry, asbestos-cement industry, shipbuilding and repair activities are located there. Data on mesothelioma cases have been already published [45].

The geographical distribution of municipal SMRs confirms the geographical North-South trend of past asbestos use: municipalities with significantly increased SMRs are mainly located in northern part of the coun-

\begin{tabular}{|c|c|c|c|c|c|c|c|c|}
\hline \multirow[b]{3}{*}{ IPS } & \multicolumn{4}{|c|}{ Males } & \multicolumn{4}{|c|}{ Females } \\
\hline & \multicolumn{2}{|c|}{$\begin{array}{c}1995-2002 \\
\text { Malignant neoplasm } \\
\text { of pleura ICD-9 } 163\end{array}$} & \multicolumn{2}{|c|}{$\begin{array}{c}\text { 2003-2009* } \\
\text { Mesothelioma } \\
\text { of pleura ICD-10 C45.0 }\end{array}$} & \multicolumn{2}{|c|}{$\begin{array}{c}1995-2002 \\
\text { Malignant neoplasm } \\
\text { of pleura ICD-9 } 163\end{array}$} & \multicolumn{2}{|c|}{$\begin{array}{c}\text { 2003-2009* } \\
\text { Mesothelioma } \\
\text { of pleura ICD-10 C45.0 }\end{array}$} \\
\hline & Obs & SMR $(90 \%$ CI) & Obs & SMR (90\% Cl) & Obs & SMR (90\% Cl) & Obs & SMR $(90 \% \mathrm{Cl})$ \\
\hline Area Litorale vesuviano & 49 & $174(135-221)$ & 23 & $189(129-268)$ & 23 & $159(109-225)$ & 4 & $75(26-173)$ \\
\hline Aree industriali Val Basento & ** & - & 3 & $430(117-1111)$ & ** & - & ** & - \\
\hline Balangero & 3 & $278(76-719)$ & 2 & $265(47-836)$ & ** & - & ** & - \\
\hline Bari - Fibronit & 49 & $199(155-253)$ & 26 & 189 (133-262) & 17 & $192(122-287)$ & 17 & $279(178-419)$ \\
\hline Biancavilla & 6 & $439(191-867)$ & 5 & $654(258-1375)$ & 4 & $612(209-1401)$ & 5 & 2293 (904-4822) \\
\hline Broni & 22 & $1433(970-2046)$ & 11 & $1145(642-1895)$ & 13 & $1340(793-2131)$ & 13 & 2185 (1293-3475) \\
\hline Casale Monferrato & 147 & $827(718-950)$ & 110 & 1015 (861-1189) & 121 & $1011(864-1177)$ & 85 & $1324(1097-1586)$ \\
\hline Emarese & ** & - & ** & - & ** & - & ** & - \\
\hline Massa Carrara & 29 & 231 (165-315) & 19 & $228(149-334)$ & 3 & $60(16-154)$ & 3 & $127(35-327)$ \\
\hline Pitelli & 104 & $198(167-233)$ & 77 & 239 (196-289) & 12 & $81(47-131)$ & 12 & 147 (85-239) \\
\hline Priolo & 29 & $260(186-354)$ & 28 & 444 (315-608) & 10 & $193(105-327)$ & 4 & $226(77-518)$ \\
\hline Tito & $\star \star$ & - & $\star \star *$ & - & ** & - & $* *$ & - \\
\hline
\end{tabular}


try. The cluster analysis is more specific and less sensitive that SMR analysis and less influenced by chance, but it may not be able to detect individual municipalities with increased risk because of limited sample size.

The novel findings produced by the present study can thus be summarized as follows. In 2003-2009, excluding 2004 and 2005 years, 5184 deaths per year from pleural mesothelioma occurred. The overall spatial distribution was consistent with previous findings, although some clusters were here reported for the first time and for some of them previous documentation of asbestos exposure was unavailable (i.e. Collesalvetti, Collecchio, Fidenza, Sala Baganza) so that ad hoc investigations are now specifically required in these contexts.

\section{CONCLUSIONS}

In light of the findings of the present study, and of the subsequent discussion, some conclusions are warranted.

The study of the geographic distribution of pleural mesothelioma in Italy, especially the cluster analysis, has lead to the detection of several areas of the country where the burden of asbestos-related disease is evident. Occupational and environmental asbestos exposures in these areas appear to have consistently been elevated and long-lasting.

Several among the clusters showed in Figures 2 and 3 (namely, Casale Monferrato, Broni, Carrara, Bari, Biancavilla, Augusta and Siracusa) are included among the sites of national concern for environmental remediation, because of the presence of asbestos (see Table 3). The clusters of Trieste, Livorno and Taranto correspond to IPSs where asbestos is not mentioned in the Decree, but characterized by the presence of harbour area; interestingly, in all three these sites, available epidemiological evidence strongly supports the presence of relevant occupational and environmental asbestos exposure.

As far as the remaining clusters are concerned, and in many individual municipalities characterized by high mesothelioma mortality rates, it is necessary to rank priorities of intervention and to evaluate the effectiveness of environmental remediation. This process requires an approach based on the integration of available environmental and health data, to be performed by an interdisciplinary working group including central and local institutions committed to environmental protection and public health.

This activity requires, beyond technical skill, both transparency and equity. Transparency implies involvement of the media and of various stakeholders, including environmental associations and representatives of affected communities, including victim organizations. Equity has to be pursued by ranking priorities in order to favour worst-off situations, in terms of exposure levels, health impacts, and socioeconomic deprivation. Environmental remediation might thus be experienced as a starting point of a global process of development for those communities that have been severely affected by the prevailing industrialization models of the past.

\section{Conflict of interest statement}

There are no potential conflicts of interest or any financial or personal relationships with other people or organizations that could inappropriately bias conduct and findings of this study.

Received on 23 June 2012.

Accepted on 5 July 2012.

\section{References}

1. International Agency for Research on Cancer. Monograph on the Evaluation of Carcenogenic Risks to Humans. Lyon: IARC; 2012. Vol.100C:219-309.

2. International Agency for Research on Cancer. Monograph on the Evaluation of Carcinogenic Risks to Humans. Lyon: IARC; 2012. Vol. 100C: 312-316.

3. Comba P, Gianfagna A, Paoletti L. Pleural mesothelioma cases in Biancavilla are related to a new fluoro-edenite fibrous amphibole. Arch Environ Health 2003;58:229-32. http://dx.doi.org/10.3200/AEOH.58.4.229-232

4. Di Paola M, Mastrantonio M, Comba P, Grignoli M, Maiozzi P, Martuzzi M. Territorial distribution of mortality from malignant tumors of the pleura in Italy. Ann Ist Super Sanità 1992;28(4):589-600.

5. Di Paola M, Mastrantonio M, Carboni M, Belli S, Grignoli M, Comba P, Nesti M. Mortality from malignant pleural neoplasms in Italy in the years 1988-1992. Roma: Istituto Superiore di Sanità; 1996. (Rapporti ISTISAN, 96/40).

6. Mastrantonio M, Belli S, Binazzi A, Carboni M, Comba P, Fusco P, Grignoli M, Iavarone I, Martuzzi M, Nesti M, Trinca S, Uccelli R. Mortality from malignant pleural neoplams in Italy (1988-1997). Roma: Istituto Superiore di Sanità; 2002. (Rapporti ISTISAN, 02/12).

7. Marinaccio A, Scarselli A, Binazzi A, Altavista P, Belli S, Mastrantonio M, Pasetto R, Uccelli R, Comba P. Asbestos related diseases in Italy: an integrated approach to identify unexpected professional or environmental exposure risks at municipal level. Int Arch Occup Environ Health 2008;81:993-1001. http://dx.doi.org/10.1007/s00420-007-0293-x

8. Fazzo L, De Santis M, Minelli G, Bruno C, Zona A, Marinaccio A, Conti S, Comba P. Pleural mesothelioma mortality and asbestos exposure mapping in Italy. Am J Ind Med 2012;55:1124. http://dx.doi.org/10.1002/ajim.21015

9. Bruno C, Comba P, Maiozzi P, Vetrugno T. 1996. Accuracy of death certification of pleural mesothelioma in Italy. Eur $J$ Epidemiol 1996;12:421-3. http://dx.doi.org/10.1007/BF00145308

10. Gorini G, Merler E, Chellini E, Crocetti E, Costantini AS. Is the ratio of pleural mesothelioma mortality to pleural cancer mortality approximately unity for Italy? Considerations from the oldest regional mesothelioma register in Italy. $\mathrm{Br} \mathrm{J}$ Cancer 2002;86:1970-1. http://dx.doi.org/10.1038/sj.bjc.6600363

11. Marinaccio A, Binazzi A, Marzio DD, Scarselli A, Verardo M, Mirabelli D, Gennaro V, Mensi C, Riboldi L, Merler E, 
De Zotti R, Romanelli A, Chellini E, Silvestri S, Pascucci C, Romeo E, Menegozzo S, Musti M, Cavone D, Cauzillo G, Tumino R, Nicita C, Melis M, Iavicoli S, ReNaM Working Group. Pleural malignant mesothelioma epidemic. Incidence, modalities of asbestos exposure and occupations involved from the Italian national register. Int $J$ Cancer 2012;130(9):2146-54.

http://dx.doi.org/10.1002/ijc.26229

12. Mirabelli D, Roberti S, Gangemi M, Rosato R, Ricceri F, Merler E, Gennaro V, Mangone L, Gorini G, Pascucci C, Cavone D, Nicita C, Barbieri PG, Marinaccio A, Magnani C, Montanaro F. Survival of peritoneal malignant mesothelioma in Italy: a population-based study. Int J Cancer 2009;124(1):194-200.

http://dx.doi.org/10.1002/ijc.23866

13. Montanaro F, Rosato R, Gangemi M, Roberti S, Ricceri F, Merler E, Gennaro V, Romanelli A, Chellini E, Pascucci C, Musti M, Nicita C, Barbieri PG, Marinaccio A, Magnani C, Mirabelli D. Survival of pleural malignant mesothelioma in Italy: a population-based study. Int J Cancer 2009;124(1):201-7. http://dx.doi.org/10.1002/ijc.23874

14. Marinaccio A, Binazzi A, Cauzillo G, Cavone D, De Zotti R, Ferrante P, Gennaro V, Gorini G, Menegozzo M, Mensi C, Merler E, Mirabelli D, Montanaro F, Musti M, Pannelli F, Romanelli A, Scarselli A, Tumino R, Italian mesothelioma register (ReNaM) working group. Analysis of latency time and its determinants in asbestos related malignant mesothelioma cases of the Italian register. Eur $J$ Cancer 2007;43(18):2722-8

http://dx.doi.org/10.1016/j.ejca.2007.09.018

15. Marinaccio A, Montanaro F, Mastrantonio M, Uccelli R, Altavista P, Nesti M, Seniori Costantini A, Gorini G. Predictions of mortality from pleural mesothelioma in Italy: a model based on asbestos consumption figures supports results from age-period-cohort models. Int $J$ Cancer 2005;115(1):142-7.

http://dx.doi.org/10.1002/ijc.20820

16. Paglietti F, Di Molfetta V, Malinconico S, Giangrasso M, Bellagamba S, Damiani F. Italian asbestos mapping. World Asbestos Conference; 2009.

17. Pirastu R, Iavarone I, Pasetto R, Zona A, Comba P. SENTIERI Project. Mortality study of residents in Italian polluted sites. Results. Epidemiol Prev 2011;35(Suppl. 4):1204.

18. Kuldorff M. A spatial scan statistic. Commun Stat Theory Meth 1997;26:481-96. http://dx.doi.org/10.1080/03610929708831995

19. Maule MM, Magnani C, Dalmasso P, Mirabelli D, Merletti F, Biggeri A. Modeling mesothelioma risk associated with environmental asbestos exposure. Environ Health Perspect 2007;115:1066-71.

http://dx.doi.org/10.1289/ehp.9900

20. López-Abente G, Fernández-Navarro P, Boldo E, Ramis R, García-Pérez J. Industrial pollution and pleural cancer mortality in Spain. Science Tot Environ 2012;424:57-62. http://dx.doi.org/10.1016/j.scitotenv.2012.02.047

21. Bianchi C, Grandi G, Di Bonito L. Diffuse pleural mesothelioma in Trieste. A survey based on autopsy cases. Tumori 1978;64(6):565-70.

22. Bianchi C, Brollo A, Ramani L, Zuch C. Asbestos-related mesothelioma in Monfalcone, Italy. Am J Ind Med 1993;24(2):149-60.

http://dx.doi.org/10.1002/ajim.4700240203

23. Bianchi C, Brollo A, Ramani L, Bianchi T, Giarelli L. Asbestos exposure in malignant mesothelioma of the pleura: a survey of 557 cases. Ind Health 2001;39(2):161-7. http://dx.doi.org/10.2486/indhealth.39.161
24. Bianchi C, Bianchi T, Tommasi M. Mesothelioma of the pleura in the Province of Trieste. Med Lav 2007;98(5):374-80.

25. Giarelli L, Bianchi C, Grandi G. Malignant mesothelioma of the pleura in Trieste, Italy. Am J Ind Med 1992;22(4):521-30. http://dx.doi.org/10.1002/ajim.4700220407

26. Magnani C, Terracini B, Bertolone GP, Castagneto B, Cocito V, De Giovanni D, Paglieri P, Botta M. Mortality from tumors and other diseases of the respiratory system in cement-asbestos workers in Casale Monferrato. A historical cohort study. Med Lav 1987;78:441-53.

27. Ferrante D, Bertolotti M, Todesco A, Mirabelli D, Terracini B, Magnani C. Cancer mortality and incidence of mesothelioma in a cohort of wives of asbestos workers in Casale Monferrato, Italy. Environ Health Perspect 2007;115(10):1401-5. http://dx.doi.org/10.1289/ehp.10195

28. Barbieri PG, Mirabelli D, Somigliana A, Cavone D, Merler E. Asbestos fibre burden in the lungs of patients with mesothelioma who lived near asbestos-cement factories. Ann Occup Hyg 2012;56(6):660-70. [Epub ahead of print]. http://dx.doi.org/10.1093/annhyg/mer126

29. Magnani C, Comba P, Di Paola M. Pleural mesotheliomas in the Po river valley near Pavia: mortality, incidence and correlations with an asbestos cement plant. Med Lav 1994;85(2):157-60.

30. Amendola P, Belli S, Binazzi A, Cavalleri A, Comba P, Mastrantonio M, Trinca S. Mortality from malignant pleural neoplasms in Broni (Pavia). 1980-1997. Epidemiol Prev 2003;27(2):86-90

31. Puntoni R, Merlo F, Borsa L, Reggiardo G, Garrone E, Ceppi M. A historical cohort mortality study among workers in Genoa, Italy. Am J Ind Med 2001;40:363-70. http://dx.doi.org/10.1002/ajim.1110

32. Dodoli D, Del Nevo M, Fiumalbi C, Iaia TE, Cristaudo A, Comba P, Viti C, Battista G. Environmental household exposures to asbestos and occurrence of pleural mesothelioma. Am J Ind Med 1992;21:681. http://dx.doi.org/10.1002/ajim.4700210508

33. Gennaro V, Finkelstein MM, Ceppi M, Fontana V, Montanaro F, Perrotta A, Puntoni R, Silvano S. Mesothelioma and lung tumors attributable to asbestos among petroleum workers. Am J Ind Med 2000;37:275-82.

http://dx.doi.org/10.1002/(SICI)1097-0274(200003)37:3<275: :AID-AJIM5>3.0.CO;2-I

34. Pira E, Pilucchi C, Buffoni L, Palmas A, Turbiglio M, Negri E, Piolatto PG, La Vecchia C. Cancer mortality in a cohort of asbestos textile workers. Br J Cancer 2005;92:580-6. http://dx.doi.org/10.1038/sj.bjc.6602240

35. Mirabelli D, Stura A, Gangemi M, Bertolotti M, Maule MM, Magnani C. Incidence of malignant mesothelioma in Piedmont, 1990-2001. Epidemiol Prev 2007;31(2-3):132-8.

36. Mangone L, Romanelli A, Campari C, Candela S. Malignant mesothelioma in Emilia Romagna: incidence and asbestos exposure. Epidemiol Prev 2002;26(3):124-9.

37. Raffaelli I, Festa G, Costantini AS, Leva G, Gorini G. Mortality in a cohort of asbestos cement workers in Carrara, Italy. Med Lav 2007;98:156-63.

38. Nemo A, Boccuzzi MT, Silvestri S. Asbestos import in Italy: the transit through Livorno harbour from 1957 to 1995. Epidemiol Prev 2009;33(1-2):59-64.

39. Maltoni C, Lambertini L, Cevolani D, Minardi F, Soffritti M. The mesotheliomas related to asbestos used in Italian railway: report of 199 cases. Eur J Oncol 2002;7:51-5.

40. Belli S, Bruno C, Comba P, Grignoli M. Cause-specific mortality of asbestos-cement workers compensated for asbestosis in the city of Bari. Epidemiol Prev 1998;22:8-11.

41. Coviello V, Carbonara M, Bisceglia L, Di Pierri C, Ferri 
GM, Lo Izzo A, Porro A, Sivo D, Assennato G. Mortality in a cohort of asbestos cement workers in Bari. Epidemiol Prev 2002;26:65-70.

42. Musti M, Pollice A, Cavone D, Dragonieri S, Bilancia M. The relationship between malignant mesothelioma and an asbestos cement plant environmental risk: A spatial casecontrol study in the city of Bari (Italy). Int Arch Occup Environ Health 2009;82:489-97.

http://dx.doi.org/10.1007/s00420-008-0358-5

43. Graziano G, Bilancia M, Bisceglia L, de Nichilo G, Pollice
A, Assennato G. Statistical analysis of the incidence of some cancers in the province of Taranto 1999-2001. Epidemiol Prev 2009;33(1-2):37-44.

44. Bruno C, Comba P, Maiozzi P, Vetrugno T. Accuracy of death certification of pleural mesothelioma in Italy. Eur J Epidemiol 1996;12:421-3.

http://dx.doi.org/10.1007/BF00145308

45. Madeddu A, Contrino L, Tisano F, Sciacca S. Cancer in Syracuse (Italy), from 2002 to 2005. Registro Territoriale di Patologia AUSL 8. Siracusa; 2009. p. 138 [in Italian]. 